\title{
64. Türk komedi filmlerinin bağıntı kuramı bağlamında sesli betimlenmesi: Neşeli Günler ${ }^{1}$
}

Pelin ŞULHA ${ }^{2}$

\begin{abstract}
APA: Şulha, P. (2021). Türk komedi filmlerinin bağıntı kuramı bağlamında sesli betimlenmesi: Neșeli Günler. RumeliDE Dil ve Edebiyat Araştırmaları Dergisi, (22), 991-1004. DOI: 10.2900o/rumelide.897310.
\end{abstract}

\section{$\ddot{O} \mathbf{z}$}

Çeviri alanında engelsiz erişim için yapılan çeviri türlerinden biri olarak araştırmalara konu olan sesli betimleme ülkemizde giderek ilgi çekmektedir. Medya ürünlerini uygun formatlarda görme engelliler için erişilebilir hale getirme işlemi olan sesli betimlemenin en sık uygulandığı ortamlardan biri özellikle yerli komedi filmleridir. Bu makalede Neşeli Günler (1978) adlı klasikleşmiş bir Türk komedi filminin sesli betimlemesi bilişsel edimbilimsel bir bakış açısıyla bağıntı kuramı çerçevesinde irdelenmiştir. Görme engellilerin diğer seyirciler gibi komik sahnelere gülebilmeleri için işitme yoluyla erişemedikleri görsel bilgilerin betimlemede yer alması gereklidir. Sesli betimlemede bir sahnenin içerdiği görsel bilgileri tümüyle iletmekten ziyade, diyaloglar arasındaki boşluk süreleri de göz önüne alınarak mevcut bilgilerle bağlamsal bilgiler yorumlandığında ortaya çıkan bilişsel etkilerin gülme tepkisinin oluşumunu sağlayacak şekilde seyircinin en az çabayla işlemleyebileceği en bağıntılı görsel bilgilerin seçilmesi önemlidir. Bu çalışmada sosyo-kültürel dokumuzun döneme özgü komedi anlayışını yansıtan sahnelerde bu ilkeyi temel alan çevirmenin metin yazarı olarak betimleme metnini nesnel ve öznel yaklaşımlarla nasıl oluşturduğu incelenmiştir.

Anahtar kelimeler: Görsel-işitsel çeviri, sesli betimleme, bilişsel edimbilim, bağıntı kuramı, Türk Komedi filmleri

\section{Audio description of Turkish comedy films in the frame of relevance theory: Neşeli Günler}

\begin{abstract}
Audio description as a form of accessibility and a topic widely researched in the field of translation studies has been increasingly attracting interest in our country. Audio description is a process making media products accessible in appropriate formats to the visually impaired individuals. Domestic comedy films are one media where audio description is utilized extensively. This article looks into the audio description of a classic Turkish comedy film Neşeli Günler (1978) (Happy Days) from a cognitive pragmatics perspective in the framework of relevance theory. Visual information that visually impaired cannot access through hearing must be provided in the description text so that they can laugh at funny scenes just like the other spectators. Instead of transferring the entire visual information in the scene, considering the gaps between dialogues, the most relevant visual information necessitating minimum effort should be selected which ensures that the emerging
\end{abstract}

Bu makale 2017-2019 yılları arasında Dokuz Eylül Üniversitesi özgelirleriyle desteklenen Dr. Öğr. Üyesi Pelin Şulha'nın yürütücülüğünü yaptığı Sesli Betimleme Destek Projesi başlıklı 2017.KB.SOS.012 numaralı araştırma projesinden üretilmiştir.

Dr. Ö̆̆gr. Üyesi, Dokuz Eylül Üniversitesi, Edebiyat Fakültesi, Mütercim-Tercümanlık Bölümü, İngilizce MütercimTercümanlık ABD (İzmir, Türkiye) pelin.sulha@deu.edu.tr ORCID ID: 00oo-0002-0515-141X [Araştırma makalesi, Makale kayt tarihi: 10.02.2021-kabul tarihi: 20.03.2021; DOI: 10.29000/rumelide.897310]

\section{Adres $\mid$ Address}


cognitive effects following the audience's interpretation of his/her existing and contextual information results in the production of laughter. This study explores the scenes that reflect the concept of comedy specific to the given period of our socio-cultural texture, and how the translator as a script writer composes the description by an objective and/or subjective approach.

Keywords: Audiovisual translation, audio description, cognitive pragmatics, relevance theory, Turkish comedy films

\section{Giriş}

Sesli betimleme görme engellilerin istedikleri ve gereksinim duydukları görsel-işitsel ürünlere erişimini sağlamak için yapılan bir çeviri türüdür. Ülkemizde medya erişilebilirliğinin önem kazanmasıyla görsel-işitsel çeviribilim araştırmaları kapsamında gün geçtikçe ön plana çıkan sesli betimleme uygulamalarından en çok yararlanılan ortamlardan biri yerli filmlerdir. Sesli betimlemeli filmler görme engelli seyircilerin filmleri kolaylıkla takip etmelerine olanak sağlayarak onlara, görme engeli olmayan seyircilerin yaşadığına olabildiğince benzer bir film seyretme deneyimi sunmayı hedefler. Sesli betimleme filmin anlaşılmasında gerekli olan görsel unsurları yer ve zaman kısıtlamalarını göz önünde bulundurarak berrak bir dille aktarmayı içerir. Metin yazarlığı görevini üstlenen çevirmenin süreç içinde çözmesi gereken kritik mesele, film sahnelerinde yer alan her bir görsel unsurun aktarılması mümkün olmadığından hangi unsurların nasıl aktarılacağını saptamaktır. Çevirmenin bu seçimlerinde belirleyici etkenlerden biri de betimleyeceği filmin türüdür. Bu makalede incelenecek olan film Neşeli Günler komedi olduğu için seyirciyi güldürmeyi hedeflemektedir, dolayısıyla betimlemede Türk seyircisi üzerinde gülme tepkisi uyandıran veya işitilenlerden ortaya çıkan komik tesiri destekleyici nitelikteki görsel unsurların anlatılması beklenir. Bu bağlamda Dan Sperber ve Deidre Wilson'un $(1986 / 1995,1987)$ Paul Grice'in $(1961,1989)$ öne sürdüğü konuşma kurallarından biri olan konuşma esnasında söylenenlerin birbiriyle ilişkili olması gerektiğini vurgulayan bağıntı ilkesinden yola çıkarak ortaya koyduğu bağıntı kuramı sesli betimlemeye uyarlanabilir. Görme engelliler, betimleme metninde yer alanlar ve işittikleri arasında ne kadar az zihinsel işlemleme yaparak, yani kısa sürede eski ve yeni bilgilerden çıardığı sonuçlarla orijinal filmdeki komik bağı kurabilirse, bu metnin o derece bağıntılı ve komedi film türünün işlevine uygun olarak hazırlandığı anlamına gelir. Bu makalede 1970'li yılların Türk kültür, toplum ve aile yaşantısına ayna tutan Yeşilçam sinemasının klasik güldürülerinden Neşeli Günler filminden seçilen sahnelerin sesli betimleme süreci bağıntı kuramı çerçevesinde irdelenecektir. Dönemin beden dili, jest ve mimikleri önceleyen komedi anlayışının vurgulandığı bu sahnelerin ayrıntılı ifade veya yorum şeklinde nesnellik/öznellik düzleminde betimlenerek görme engelli seyirciler için nasıl erişilebilir hale getirildiği tartışlacaktır.

\section{Film sesli betimlemeleri}

Görsel-İşitsel Çeviri (AVT) dinamik ve yeniliklere açık bir araştırma alanıdır. Günümüzde bu alanın nispeten özgün bir konuma sahip olması, dijital çağın koşullarına uyum sağlama çabalarının çeviribilime getirdiği geniş kapsamlı bakış açısıyla açıklanabilir. Görme engellilerin görsel-işitsel ürünlere erişimini sağlamak için kullanılan sesli betimleme tekniğinin bu anlamda önemli katkıları olmuştur. Sesli betimleme görsel-işitsel çeviri alanında medya erişilebilirliği kapsamında çalışılmaktadır. Görselliğin ve ekran odaklı iletişimin yaşamın vazgeçilmez bir parçası olduğu günümüz dünyasında her yaş grubundan ve toplumun her kesiminden farklı özelliklerde bireylerin iş, bilgi, eğitim ve eğlence kaynaklarına erişebilmesi öncelikli bir gereksinim ve yaşama eşit imkânlarda

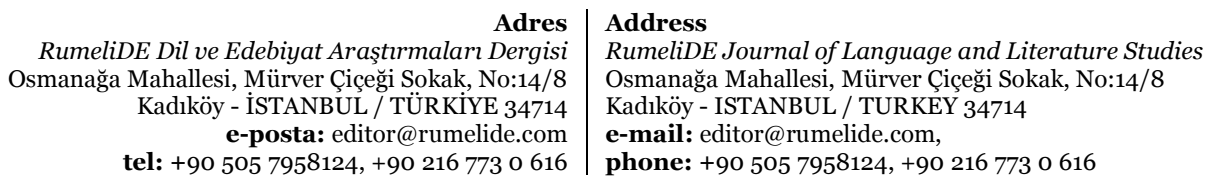


tam anlamıyla katılımı sağlayan bir hak olmuştur. Bu gereksinimi karşılayabilmek farklı ortamlarda bireylere uygun formatlarda ürünlerin tasarlanması ve üretilmesi ile mümkün olabilir. Görme yetisini kaybetmiş veya az gören bireylerin bu engellerini aşmaları algılayamadıkları görsel unsurların onlara aktarılmasıyla yani sesli betimleme yoluyla sağlanabilir. Her türde görsel-işitsel malzeme sesli betimlenebilir örneğin yağlıboya tablolar, tiyatro ve bale gösterileri, karikatürler. Yerli ve yabancı filmler sesli betimlemesi en çok yapılan ürünler arasında yer alır (Şulha, 2019). Sesli betimlemeyi Roman Jakobson'un diliçi, dillerarası ve göstergelerarası çeviri olarak tanımladığı üç çeviri türü kapsamında da ele almak mümkündür (1959: 233). İlk etapta zaten film sahnesindeki görsel göstergeler betimlemede dilsel göstergelerle karşılandığı için göstergelerarası çeviridir. Mesela bu çalışmada olduğu gibi yerli bir film Türk görme engelli seyircileri için betimlenirse diliçi çeviri, eğer dublajlı bir Fransız filmi yine Türkçe betimlenirse dillerarası çeviri olarak değerlendirilir. Filmler betimlenirken diyaloglar arasındaki boşluklara film müzikleri ve ses efektlerini olabildiğince kesmeden görme engellilerin filmi anlaması için bilmesi gereken görsel unsurları betimleyen ek bir anlatı yerleştirilir ve seslendirilir, böylece görsel olan sözel ve işitsel olana dönüşür. Görme engelli seyirci bu anlatıyı dinleyerek gören seyircilerinkine benzer deneyimlerle filmi takip edebilir duruma gelir. Amerikalı sesli betimleme sanatçısı Joel Snyder bu uygulamanın hedefini gerçekleştirmesi için betimleyenin/çevirmenin gözlemci kimliğiyle yaşadığı dünyayı içinden görmesi yani etrafında olup bitenlere yakından bakması ve alıcı gözle incelemesinin gerekli olduğunu vurgular. Ayrıca metin yazarı olarak çevirmen filmde sahnelerin anlaşılması için betimleme metnine öncelikli olarak eklenecek görsel unsurlara karar vermelidir. Bu unsurlar sözle anlatılırken seçilen ifadelerin görme engellilerin dış dünyayı algılama biçimlerine uygun olmasına ve adeta bir kameradan yansıyan görüntüler netliğinde canlı ve nesnel bir dil kullanılmasına özen gösterilmelidir. Betimlemeye ayrılan boşlukların yer ve uzunluk bakımından ne ölçüde elverişli veya kısıtlayıcı olduğunun değerlendirilmesi metnin şekillenmesinde önemli rol oynar (2008: 195).

\section{Çeviribilime bilişsel edimbilimsel yaklaşım}

Bildirişimi farklı bakış açılarıyla değerlendiren ve özetle sözcenin yorumlanması olarak tanımlanan edimbilim insanların birbirlerini bu denli anlayabilmelerinin ardındaki sırlı gerçekleri keşfetmek için epey zamandır çaba göstermektedir. Temel amacı yazılı ve sözlü iletişim sağlamak olan çeviri edimine, bireylerarası iletişimi ve edimbilimi bilişsel yönleriyle inceleyen bağıntı kuramı çerçevesinde yaklaşmak, yorumlama ve alımlama süreçlerini irdelemek bakımından önem taşır (Doğan, 1990: 63; Kansu-Yetkiner, 2009: 110). Çeviri yapılırken gönderici ve alıcının yaşadığı bilişsel süreçlerin doğası ve işleyiş biçiminin bilinmesi, çevirmenlerin kazandıkları becerileri etkin şekilde kullanmaları ve üretecekleri erek metinlerle ilgili isabetli kararlar almalarında önemli ölçüde rol oynar. Bu nedenle çeviri süreci odaklı incelemelerde dilbilim ve psikoloji perspektifiyle bağlamsal anlamı bilişsel ilkeler kapsamında araştıran bilişsel edimbilim uygun kuramsal çerçeveyi oluşturur. Günümüze kadar bilişsel edimbilim alanında geliştirilen kuramlar arasında öne çıkan Dan Sperber ve Deidre Wilson'un (1986/1995, 1987) Paul Grice'ın (1961, 1989) çlkarımsal bildirişim odaklı görüşlerinden esinlenerek ortaya koyduğu bağıntı kuramı, bilişsel edimbilim temelli çeviri araştırmalarına ışık tutan tek kuram olmasından dolayı çeviribilim alanında ayrı bir yere sahiptir. Bu kuramsal yaklaşım çeviri metinleri ürün olarak irdeleyen araştırmacıların bunun yanı sıra çeviri eylemini detaylarıyla anlayabilmek için çeviri sürecinde gerçekleşen zihinsel işlemleri mercek altına alarak özgün nitelikte çalışmalar yürütmelerinin yolunu açmıştır (Gallai, 2019: 51-52, 65).

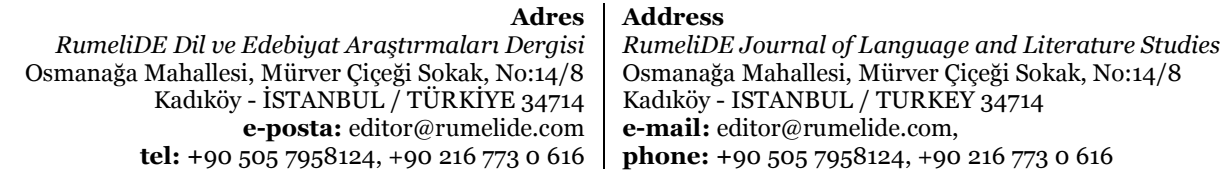

tel: +90 505 7958124, +90 2167730616 


\section{Bağıntı kuramı}

Grice'ın konuşma sezdirimleri kuramı edimbilimde dönüm noktalarından biri olmuştur. Bu kurama göre iletişimde önemli olan konuşucunun söyledikleri değil, söyledikleriyle aslında neyi kastettiğidir. Dolayısıyla deyim yerindeyse insanların birbirlerinin dilinden anlayabilmesi ve iletişimin tam anlamıyla gerçekleşmesi dinleyicinin konuşucunun niyetini doğru olarak sezmesi koşuluna bağlıdır. Grice iletişimi dilin sunduğu çeşitli olanakları göz ardı eden indirgemeci bir yaklaşımla ele almaktan kaçınır. İletişim konuşucunun düşüncelerini dil vasıtasıyla kodlayıp, dinleyicinin söylenene anlam yüklemek için bu kodu çözdüğü basit bir süreçten ibaret değildir. Dinleyicinin işlevi konuşucunun söylediklerinden esas niyetine yönelik varsayımlar üretip, uygun çıkarımlar yapmak yani konuşma esnasında ima edileni sezmektir. Günlük hayatımızda konuşurken düşüncelerimizi çoğunlukla açıkça ifade etmeyiz. Ama bizi dinleyenin söylediklerimizin özünde yatan düşünceyi doğru anlamasını bekleriz, örneğin bir konuşucu diğerine soru sorduğunda üstü kapalı bir cevap karşısında beklenen, niyeti doğru sezebilmesi ve cevabı buna göre olumlu veya olumsuz değerlendirmesi olur (Doğan, 1990: 63-64; Doğan, 2013: 132). Bireyler arasında geçen karşılıklı iletişim kurmaya yönelik konuşmalar birbirinden bağımsız art arda dizilen sözler olarak düşünülemez. Konuşma esasen mantığa uygun olmalı ve katılımcıların konuşmanın başından belirlediği veya konuşma ilerledikçe ortaya çıkan, sınırları belirli veya tamamen belirsiz ortak bir amaç için gösterdiği işbirliği çabalarına dayanmalıdır. Grice konuşucuların konuşmalarını nasıl şekillendirmeleri gerektiğine ilişkin bu görüşlerini“konuşmanın amacı ve akışına uygun olarak gereken yerde ve gerektiği kadar konuşmak” olarak tanımladığı işbirliği ilkesinde bir araya getirir (1975: 45). İlaveten bu ilkeye bağlı dört temel kuraldan bahseder. Nicelik kuralına göre konuşma az veya çok değil gerektiği kadar bilgilendirici olmalıdır. Nitelik kuralına göre ise konuşmanın içeriği doğru ve kanıtlanabilir olmalı; konuşucu gerçekten doğruluğuna inanmadığı veya ispatı mümkün olmayan bilgiyi dinleyiciye aktarmamalıdır. Bağıntı kuralı konuşmada bağıntı kavramının altını çizer. Diğer üç kuraldan farklı olarak konuşmada ne söylendiğiyle değil söylenenin nasıl söylediğiyle ilgili olan açıllık kuralında ölçüt ise konuşmanın belirsizlik ve gereksiz sözlerden uzak anlaşılır, kısa öz ve düzenli olmasıdır (Grice, 1975: 45-46). Doğan Grice'ın bu ilke ve kurallar çerçevesinde çizdiği iletişimin idealize edilmiş bir tablo olduğuna dikkat çekerek, insanların konuşurken bu kurallara tamamıyla bağlı kaldığını varsaymanın gerçekçi bir yaklaşım olmadığını belirtir. Dinleyici konuşmanın mantık ve işbirliği üzerinden ilerlediğini düşündüğü için konuşucunun kurallardan biri veya birkaçına uymadığı durumlarda bunun geçerli bir sebebi olduğunu bilir. Bu sebebi çıkardığında her iki taraf da birbirini anlayarak başarılı bir bildirişim gerçekleştirmiş olur yani dinleyici konuşucunun sezdirimlerini çözümleyerek ona aslında ne söylemek istediğini anlar (1990: 64).

Grice'ın bu görüşleri insanların birbirini anlama sürecini bilişsel boyutlarıyla ele alan bağıntı kuramı için çıkış noktası olmuştur (Doğan, 2013: 132). Sperber ve Wilson'un (1986) ortaya koyduğu bu kuram “...düşünen, yorumlayan ve dilbilgisel olarak her zaman kurallı tümce kurmayan insan iletişimi üzerinde yoğunlaşmıştır... Grice’ın betimleyici yaklaşımına karşlık açıklayıcı ve çözümleyici bir bakış açısı sunmuştur" (Kansu-Yetkiner, 2009: 8).Bireyler arasında geçen konuşmalar esnasında zihinde neler yaşandığına değinmediği için Grice'ı eleştiren Sperber ve Wilson bilişsel odaklı bağıntı kuramının iletişime her yönüyle açılklk getirebilen yegâne kuram olduğunu savunur (Doğan, 2013: 132-133). Bu kuramın Grice'ın diğer konuşma kurallarından ayrıştırarak özellikle ele aldığı “...Bağıntı İlkesi bilişsel bir anahtar işlevini üstleniyor: insan bildirişimini düzenliyor, insanların anlaşabilmelerini sağlıyor ve en önemlisi bu anlaşmanın nasıl gerçekleştiğini açıklıyor. 'Anahtar' benzetmesini sürdürürsek, Bağıntı İlkesi SW’e göre edimbilimde her kapıyı açıyor” (Doğan, 1990: 66). Bağıntı kuramına göre bilişsel süreçleri harekete geçiren iç ve dış uyaranlar örneğin görüntüler, sesler,

\begin{tabular}{r|l} 
Adres & Address \\
RumeliDE Dil ve Edebiyat Arastirmalar Dergisi & RumeliD
\end{tabular}

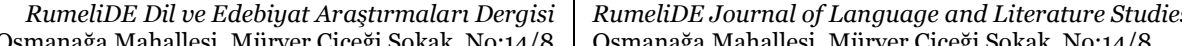
Osmanağa Mahallesi, Mürver Çiçeği Sokak, No:14/8 e-posta: editor@rumelid tel: +90 505 7958124, +90 2167730616

Kadıköy - ISTANBUL / TURKEY 34714

e-mail: editor@rumelide.com,

phone: +90 $5057958124,+902167730616$ 
sözceler, düşünceler, anılar vb. girdiler insanla bir şekilde bağıntılı olabilir. Dinleyici konuşucunun ilettiği her sözceyi konuşmayla bağıntılı olduğunu düşünerek algılar. İnsan bilişinin doğasında olan bu bağıntı arayışı sebebiyle sadece bağıntı kurabileceği uyaranlar onun ilgisini çeker. İnsanın bu eğiliminin farkında olmak iletişime katılanların öngörüde bulunarak süreci etkili yönetmesi bakımından faydalı olabilir. İster bir film karesi, ister doğadaki sesler, yolda rastladığınız birinin söylediği söz veya çocukluğunuzdan kalan mutlu anlar olsun herhangi bir girdinin bireye bağıntılı gelmesi için bireyin bu girdiyi kendi artalan bilgisiyle ilişkilendirmesi ve anlamlı sonuçlar çıkarabilmesi gereklidir. Bu farklı içerikteki sonuçlar bireyin aklını kurcalayan bir sorunun yanıtından tutun da, bilmediği bir konuda edindiği yeni bir bilgi, işini kolaylaştıracak bir çözüm veya açlklı̆̆a kavuşan duygusal bir tepkiye kadar uzanır. Bağıntı kuramına göre bir girdi veya uyaranın birey için bağıntılı olma niteliğini bilişsel etkiler ve işlem çabası belirler. Girdinin bağıntılı sayılabilmesi mevcut varsayımlar bağlamında işlenerek olumlu bilişsel etki uyandırmasına yani bireyin yorumunu etkileyen gerçek manada bir sonucun ortaya çıkması şartına bağlıdır. Bireyin içinde bulunduğu ortamda bağıntı kurabileceği çok sayıda uyaran seçeneği olduğu için bir uyaranın öne çıkması ancak diğerlerine nazaran daha bağıntılı olmasıyla mümkün olur. Bağıntı kuramı bir girdinin işlenmesi sonucunda bıraktığı olumlu bilişsel etki ne kadar fazlaysa bu girdi o kadar bağıntılıdır veya daha açık ifadeyle bir girdi dinleyicinin o anda işine ne kadar yarıyorsa, ne kadar fayda sağlıyorsa ondan bilişsel olarak o kadar ilgi görebilir görüşünü savunur. Girdinin bilişsel etkisi kadar bu girdiyi işlemek örneğin algılamak, bellekte saklamak ve onunla ilgili çıkarımda bulunmak için harcanan çaba da o denli önemlidir. Girdiyi işlemek ne kadar çok zihinsel çaba dolayısıyla yoğun enerji gerektiriyorsa söz konusu girdi o kadar az bağıntılı olup, dinleyiciye konuşma sırasında beklediği kadar yararlı olmadığı için onun dikkatini yeterince çekmez. Konuşucu yetenekleri ve tercihleri nispetinde söylediklerinin kolay anlaşılır olmasına özen gösterirse dinleyici ilk anda sarf edeceği zihinsel çabayı değerlendirdiğinde bile olumlu bir izlenim uyanır. Konuşucunun söylediklerini gerektiği gibi düzenlediğinin göstergesi dinleyicinin sözceyi duyduğunda muhtemel başka yorumlar arasında kalmadan yaptığı ilk yorumla konuşucunun sözceyle kurmayı amaçladığı bağıntıyı kurabilmesidir (Wilson; Sperber, 2004: 608-609, 614). Doğan bu temel kuramsal tespitleri kısaca şöyle açılar:

...iletişimi bir tür 'maliyet-kazanç dengesi' olarak tanımlayan bağıntı ilkesi uyarınca, her sözce 'en az zihinsel çaba' ile yorumlanır. Bu çaba karşılığında elde edilen anlamlarla, sarf edilmiş olan zihinsel enerji arasında mutlaka makul bir denge aranır: Bir sözcenin anlamlandırılması için gereken zihinsel enerji ne kadar az ve karşılığında elde edilen anlam(lar) ne denli doyurucu ise, söz konusu sözce dinleyici için o denli bağıntılı olacaktır (2013: 133).

Bağıntı kuramına göre bir sözceyi anlamlandırmak dinleyicinin zihninde üç aşamada gerçekleşir: Dil bölmesi, eksiksiz önerme ve sezdirimler aşaması. İlk aşamada dilsel girdi bellekteki verilere erişimi olmayan ve sadece dilbilgisel çözümleme yapan dil bölmesinde işlemden geçerek beyindeki nöronların algllayacağ biçimde düşünce diline dönüştürülür. $\mathrm{Bu}$ dönüşüm sonucunda üretilen anlamsal canlandırımlar bilinç düzleminde temsil edilmeyen ve dinleyiciye anlam ifade etmeyen mantık yapılarıdır. İkinci aşamada bu anlamsal canlandırımlar bağlamdan elde edilen bilgiler ışığında genel düşünce dizgelerinde yapılan çıkarımlarla eksiksiz önermelere dönüşür. Dinleyici sözceyi doğru yorumlamak için çıkarımda bulunarak konuşucunun muallâkta bıraktığı yerleri açıklı̆ga kavuşturmalıdır örneğin Proje yarına yetişecek sözcesiyle konuşucunun saptama mı yaptığı yoksa taahhütte mi bulunduğuna karar vermelidir. Sezdirimlerin ortaya çıtığı son aşamada ise dinleyici belleğinde sakladığı bilgiler vasıtasıyla konuşucunun sözcesi hakkında oluşturduğu sezdirilen öncülü tümdengelimsel bir işleme tabi tutarak sezdirilen sonuca ulaşır, böylece doğrudan söylenmeyip sezdirilen veya ima edilen neyse anlaşlır (Doğan, 2013: 133-134). Bu işleyişi somutlaştırmak için şu örnek verilebilir:

Adres
RumeliDE Dil ve Edebiyat Araștırmaları Dergisi Osmanağa Mahallesi, Mürver Çiçeği Sokak, No:14/8 Kadıköy - ÍSTANBUL / TÜRKIYE 34714 e-posta: editor@rumelide.com tel: +90 $5057958124,+902167730616$
Address

RumeliDE Journal of Language and Literature Studies Osmanağa Mahallesi, Mürver Çiçeği Sokak, No:14/8

Kadıköy - ISTANBUL / TURKEY 34714

e-mail: editor@rumelide.com,

phone: +90 $5057958124,+902167730616$ 

A. Ayşe Cumartesi günü sinemaya gidelim mi?
B. Duygu Kapalı mekânlarda sıkılıyorum.
1. Sinema kapalı bir mekândır.
2. Kapalı mekânlardan sıkılan bir kişi, sinemaya da gidemez.
3. Duygu sinemaya gitmeyecektir.

Bu örnekte "Duygu benimle Cumartesi günü sinemaya gelecek mi?” sorusuna yanıt arayan Ayşe 1-3 arasındaki çıkarımlarda bulunduğu takdirde, Duygu'nun yanıtının olumsuz olduğunu ve onunla gelmeyeceğini anlayacaktır. Bağıntı ilkesine göre Ayşe Duygu'nun (b) cevabından yola çıkarak zihnindeki mevcut bilgileri tarar ve bir filmin gösterime sunulduğu ortamla ilgili bilgiyi seçip öncüle (1) ulaşır. Akabinde oluşturulan sezdirilen öncül (2) ve Duygu'nun yanıtı (b) tümdengelimsel bir yaklaşımla işlemlenir ve açıkça söylemeyip imayla ilettiği kuvvetle sezdirilen sonuca (3) erişilir. Juan José Martinez-Sierra bağıntı kuramı çerçevesinde iletişimin nasıl gerçekleştiğini şöyle özetler:

\begin{abstract}
İletişim sırasında açıça iletilmeyeni yorumlamak ve bilişsel etkileri çıkarsamak için alıcı ek-yeni bilgiyi (bağlamsal varsayımlar) var olan eski bilgiyle (mevcut varsayımlar)birleştirerek kullanır. Alıcı böylelikle göndericinin iletişimsel niyetini yorumlamak için cümlenin dilbilimsel anlamıyla göndericiyle paylaştığı artalan bilgisini bir araya getirir. Bu süreç zaman ve çaba gerektirir ancak bilgi bağıntılı ise karşılığında ödül olarak dünyaya bakışımızı iyileştirir veya uygun şekilde değiştirir(2009: 1).
\end{abstract}

Burada değinildiği gibi diyalog sırasında ima edilen bilgileri anlamlandırmak için dinleyici daha önce edindiği bilgiler dâhilinde ulaştığı varsayımları ve konuşucunun o anda ilettiği bilgiler bağlamında yaptığı yorumları kıyaslar. Bu işlemlemenin sonucunda kurulan bağıntı düzeyi edinilen bilgilerin bireylerin yaşantılarını nasıl etkilediğini belirler. Duygu aktarımı söz konusu olduğunda insanlar genelde aynı şeylere üzülür, ama güldükleri şeyler farklı olabilir yani filmin etkisi açısından düşünülünce, seyirciyi güldürmek onu ağlatmaktan daha karmaşı bilişsel süreçleri tetiklemeyi kapsar. Seyirci sahne ancak bağıntı kurmasına olanak verecek şekilde tasarlanmışsa gülebilir. Betimleme metninde işitsel kanaldan iletilen görsel bilgiler de bu ölçütü dikkate aldığı takdirde komedi filmi görme engellinin dünyasında anlam kazanır.

\title{
Görmeyenler işitsel komedi izlerken
}

Martinez-Sierra (2009) seçtiği Amerikan komedi filmi Borat: Cultural Learnings of America for Make Benefit Glorious Nation of Kazakhistan (Borat: Yüce Kazakistan Ulusu Amerikan Kültürü’nü Öğreniyor) ve filmin sesli betimlemeli versiyonunu kıyaslayarak komedi filmlerinin görme engelliler açısından erişilebilirliğini bağıntı kuramını temel alan edimbilimsel bir yaklaşımla irdelemiştir. Komedi film seyircisinin izleme sürecini bilişsel düzeyde nasıl deneyimlediği önemlidir. Altyazıll, dublajlı veya sesli betimlemeli herhangi bir filmin seyircisi iletişim esnasında aktif katılımcı değil sadece alıcı rolünü üstlendiği için bu görsel-işitsel ürünler tek yönlü bilgi akışının olduğu iletişim durumları olarak tanımlanır. Seyirci filmde bir sahneyi izlerken geçmiş tecrübelerini ve o anda sahnede yaşananları birlikte yorumlar. Bir başka deyişle, seyircinin eski ve yeni bilgileri işlemleyerek, sahneyi izleyene değin edinmiş olduğu dünya bilgisine dayalı mevcut varsayımlar ile sahnedeki diyaloglar, görüntüler ve sesler vasıtasıyla oluşan bağlamsal varsayımları çözümlemesi sonucunda bilişsel etkiler ortaya çıkar. Bu sayede komedi filmi seyirciyi eğlendirmek ve güldürmek işlevini yerine getirir. Görme engelli seyirci film seyrederken gören seyirciye benzer şekilde belleğindeki mevcut bilgileri kullanır ancak görüntülere erişemediği için sahne bağlamından edindiği yeni bilgiler işitsel kanaldan gelen bilgilerle sınırlı kalır. Zaten sesli betimlemenin amacı engelli seyircilerin

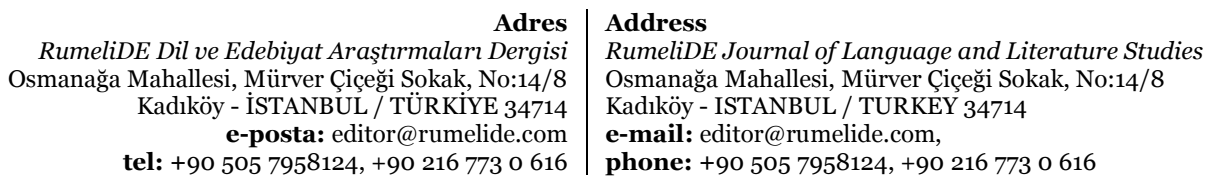


görmediklerini onlara anlatarak filmde olup bitenleri anlamaları ve istedikleri filmi kimsenin yardımına gereksinim duymadan kendi başlarına izleyebilmelerine olanak sağlamaktır. Diyaloglar ve seslerden kalan boşlukların uzunluğuna bağlı olarak eklenen bilgi değişir ve çok sayıda çeşitli görsel unsurları tamamıyla aktarmak mümkün olmadığından bağıntılı olanları seçmek gerekir. Sesli betimleme uygulamalarında orijinal bir filmin görsel kanaldan ilettiği bilgilerin engelli seyirciye yerleştirilen ek anlatıyla ne ölçüde iletilebildiği yani orijinal film metni ve betimlemeli versiyonunun yeni bilgi bakımından eşdeğerliliği temel sorunsal olarak ele alınır. Engelli seyircilerin komedi filmine gülme tepkisi vermeleri bağlama ait gerekli bilgileri betimleme vasıtasıyla alarak uygun çıkarımlarda bulunmalarına bağlıdır (2009: 2,5). Bu makalede Neşeli Günler adlı Türk filminden seçilen sahnelerde görüntüler vasitasıyla iletilen bilgilerin komedi türüne göre seçilerek betimleme metninde aktarımı irdelenecektir. Martinez-Sierra'nın (2009) çalışmasında olduğu gibi görsel öğelerin her sahnede bağıntı kuramı kapsamında mevcut varsayımlar, bağlamsal varsayımlar ve bunların etkileşimiyle ortaya çıkan sonuçlar veya bilişsel etkiler bakımından incelenmesinin yanı sıra eşdeğer tesir uyandırması beklenen betimlemenin bu edimbilimsel çözümleme neticesinde nasıl hazırlandığı yani komedi algısının oluşumunda çevirmenin metin yazarlığı süreci açıllanacaktır.

\section{Film türü}

Avrupa ülkeleri güvenilir, tutarlı ve bilimsel araştırmalara dayanan ilkeleri temel alarak kaliteli sesli betimleme hizmetleri sağlamak amacıyla 2011-2014 yılları arasında yürüttükleri ADLAB Project (Sesli Betimleme Laboratuar Projesi) sonuçlarını Pictures Painted in Words (Sözcüklerle Boyanan Resimler) (2015) başlıklı bir kılavuzda toplamıştır. Bu kılavuzun sinema ve televizyonda gösterilen kültür-sanat ürünleri ile medya ürünlerinin görme engelliler için erişilebilir hale getirilmesine yönelik çalışmalara ayrılan bölümünde anlatının temel yapı taşları olarak nitelendirilen karakterler ve eylemleri, mekân ve zaman unsurları ve film türünün sesli betimleme metni/senaryosunun hazırlanma sürecini nasıl yönlendirdiğinden bahsedilmiştir. Bu makalede ise özellikle film türünün görme engelli seyirci üzerindeki etkisinden yola çıkılarak bağıntı kuramı çerçevesinde senaryo odaklı dilbilimsel bir inceleme yapılmıştır. Her film türünün film süresince seyircisinin karşısına çıkan kendine özgü biçimsel, sanatsal ve anlatısal özellikleri vardır. Seyircinin izlediği filmin türüne aşina olması filmle ilgili genel anlamda beklentiler geliştirmesine neden olur, bu yüzden örneğin adının ele verdiği Neşeli Günler komedi filmi olduğu için ağırlıklı olarak görme engellileri güldürecek eğlenceli sahnelerdeki görsel unsurların betimlemeleri önem kazanmaktadır. Film anlatısının farklı düzeylerinde film türüne ait özellikler göze çarpar, mesela görüntünün içeriğini daha belirgin hale getiren sembolik nesneler ve mekânlar veya filmin geçtiği dönemi simgeleyen aksesuarlar. Filmde türle örtüşen görsel bir dil kullanılır, dolayısıyla metin yazarı betimlemede bu uyumu yakalamak için ikonografik unsurların yanı sıra ışık efektleri, kurgu, mizansen ve kamera çekimlerini de irdelemelidir. Filmin türü ne olursa olsun macera, dram veya polisiye, filmde sadece o belirli türe ait özellikler varsa seyirci stereotiplerin ürettiği karakterlerle karşılaşır örneğin dram filminde bir annenin şefkatli ve özverili olarak temsil edilmesi (Maszerowska, 2015).

\section{Dönemin Türk Komedi filmleri}

Türk ulusal sinemasının komedi film türüne bakış açısı çekildiği dönemlere bağlı olarak kendine özgü farklı nitelikler gösterir. Zaten genel itibariyle Türk sinema tarihinde farklı ve karmaşık bir dönem olarak görülen ve tür çalışmalarında özel bir önem atfedilen 2000'den fazla filmin üretildiği 1970-1980 yılları arasındaki yoğun on yıllık süreçte izlenen gelişmelerden temel film türlerinden biri olan komedi türü de payını almıştır (Önk, 2011: 3867). Bu yllarda toplumda yaşanan siyasi ve ekonomik

\footnotetext{
Adres $\mid$ Address

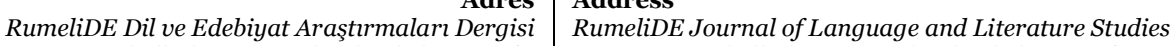
Osmanağa Mahallesi, Mürver Çiçeği Sokak, No:14/8 $\quad$ Osmanağa Mahallesi, Mürver Çiçeği Sokak, No:14/8 Kadıköy - İSTANBUL / TÜRKIYE 34714 Kadıköy - ISTANBUL / TURKEY 34714 e-posta: editor@rumelide.com e-mail: editor@rumelide.com, tel: +90 505 7958124, +90 2167730616 phone: +90 505 7958124, +90 2167730616
} 
karmaşayla beraber televizyonun günlük hayatımıza girmesi Türk sinemasını zorlu bir dönemecin eşiğine getirmiştir. Bu dalgalı ortamda seyirci odaklı bir yaklaşımla, olumlu veya olumsuz her durumu iyimserlikle karşılamaya eğilimli halkın moralini yükseltmek için çok sayıda komedi filmi çekilmesinin yanı sıra hemen her tür filmde komik sahnelere yer verilmiştir. Nijat Özön'ün (2000) tanımıyla seyirciyi eğlendirip aynı zamanda gerçeği sorgulamaya ve yaşam üzerine eleştirel düşünmeye yönelten komedi türü 1970'lerde Türk Sineması'nda gelişimini destekleyen ortamları değerlendirmiş ve süregelen komedi anlayışından kopmadan fakat değişimlere de kapılarını açık tutarak yeni bir boyut kazanmıştır. Alim Şerif Onaran'ın (1994) şarkılı taşlamalı tiyatro kabarenin sinemaya uyarlanması olarak nitelediği bu yeni tarz komedi örneklerinde mekanlar yoksul mahalleler, başrol oyuncuları ise bu mahallelerde yaşamlarını sürdüren içten ve dürüst insanlardır. Ertem Eğilmez Amerikan Sineması'nda Frank Capra'dan esinlenerek bu insanların cesaretleriyle güçlü ve kibirli görünenlere nasıl meydan okuduklarını Türk Sineması'nda uyarlayarak her kuşaktan seyirciye hitap eden en uygun komedi anlayışını getirmiştir (Önk, 2011: 3871-3872).

\section{Sesli betimleme destek projesi}

Bu çalışmada ele alınacak olan Neşeli Günler (1978) filmi Dokuz Eylül Üniversitesi bünyesinde 20172019 yıllarında bilimsel araştırma projesi olarak Mütercim-Tercümanlık Bölümü Dr. Öğr. Üyesi Pelin Şulha'nın koordinatörlüğünde yürütülmüş olan Sesli Betimleme Destek Projesi kapsamında, kendisi tarafından senaryolaştırılmış ve seslendirilmiştir. Üniversitenin görme engelli öğrencileri, çalışanları ve ülkemizde yeni gelişmekte olan sesli betimleme alanında uzmanlaşmak isteyen bölüm öğrencilerinin faydalanabileceği betimlemeli görsel-işitsel ürünlerin hazırlanması için ses stüdyosu kurulmuştur. $\mathrm{Bu}$ medya erişilebilirlik projesinin gerçekleştirilmesinde Araştırma Görevlisi Duygu Dalaslan ve Araştırma Görevlisi Emre Beyaz da görev almışlardır. Proje sürecinde bu komedi filminden başka iki yerli komedi film Süt Kardeşler (1976) ve Gülen Gözler (1977), Türkçe dublajlı animasyon The Spongebob Movie: Sponge Out of Water (2015) (Sünger Bob Kare Pantolon Suyun Dışında) ve Türkçe dublajlı yabancı film A Fistful of Dollars (1964) (Bir Avuç Dolar) üzerinde çalışılmıştır. Özetle, üç ayrı kategoride örnek filmler seçildikten sonra diyaloglar arasındaki boşlukların yerleri, süreleri ile bahsedilmesi gerekli görsel unsurlar belirlenmiş ve betimleme metinleri dinleyecek görme engelli seyirci kitlesinin özellikleri göz önüne alınarak yazılmıştır. Seslendirilen bu metinler dilsel düzeltmeler ve teknik işlemlerin ardından seyircilerin erişimine sunulmak üzere son şeklini almıştır. Bu proje görme engellilerin toplumsal yaşama dâhil olmaları, kültür-sanat etkinliklerinden diğer bireyler gibi bilgi ve eğlence kaynağı olarak yararlanmaları amacıyla sesli betimlemeye yönelik eğitim, araştırma ve uygulamaların yaygınlaşmasına kurumsal düzeyde verdiği destek ve katkılar açısından önem taşımaktadır.

\section{Sinemada Neşeli Günler}

Gelişen ve sürekli yenilenen teknolojik olanaklar sayesinde sinema sektörünün ürettiği çok sayıda sıra dışı yapıma rağmen, 1970'lerin geleneksel Türk aile yapısını ve yaşam tarzını yansıtan Neşeli Günler komedisinin hala her kuşaktan izleniyor olması seyircinin Yeşilçam filmlerine olan bağlllı̆̆ının bir göstergesi olarak görülebilir. Bu bağlllı̆̆ın arkasında geçmişin gölgesini hissetmek ve dünden bugüne toplumsal kimliğin nişanesi manevi değerleri yaşatmak düşüncesi olabilir. Sinema bireyin ve toplumun tüm zamanlarda aynasıdır. Neşeli Günler filmi geçtiği dönemin Türkiye'sini, sosyal düzen, aile ve insan ilişkilerini doğallık düsturu içinde samimiyetle anlattığı için ait olduğu toplumun geçmişini tanımak isteyen seyirciye iyi vakit geçirme vesilesi olmasının yanında değerli bir bilgi kaynağı niteliğindedir. Bu yönüyle görme engellilerin sesli betimleme vasıtasıyla Neşeli Günler filmi

\begin{tabular}{r|l} 
Adres & Address \\
RumeliDE Dil ve Edebiyat Arastrmalart Dergisi & RumeliDE
\end{tabular}

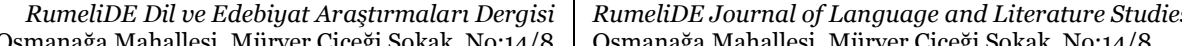
Osmanağa Mahallesi, Mürver Çiçeği Sokak, No:14/8 e-posta: editor@rumelid tel: $+905057958124,+902167730616$

Kadıköy - ISTANBUL / TURKEY 34714

e-mail: editor@rumelide.com,

phone: +90 5057958124 , +90 216773 o 616 
gibi Türk sinema tarihinin klasik sayllabilecek sinema eserlerine erişimi önemlidir. 1980 öncesi aile temalı filmlerde aile kurumu olumlu bir bakış açısıyla huzurlu, güvenli ve paylaşımların yoğun yaşandığı bir ortam olarak temsil edilmiştir (Şulha, 2019: 120; Yağbasan; Ateş, 2018: 26, 33). Neşeli Günler filmi de bu ekolün bir halkası olarak güçlü aile bağları ve aile birliğinin korunmasının her şeyden önemli olduğuna vurgu yapmıştır. Filmde Kazım Efendi (Münir Özkul) ve Saadet Hanım (Adile Naşit) İstanbul'da esnaflık yaparak 6 çocuğuyla hayatını sürdüren geçimsiz bir çifttir. Olaylı bir tartışmanın ardından boşanırlar, çocukların üçü Kazım Bey’de, diğer üçü de Saadet Hanım'da kalır. Birbirlerinin izini kaybedip yllarca görüşemeyen kardeşler tesadüf eseri karşılaşınca anne ve babalarını da bir araya getirip yeniden aile olmak isterler ama aradan geçen zamana rağmen birbirlerine kızgınlıkları hala dinmemiş olan anne babalarını barıştırmak hiç de kolay olmaz. Çocukların giriştikleri bu zor mücadele esnasında yaşanan komik olaylar filme ayrı bir renk ve canlılık katar.

\section{Seçilen sahnelerin sesli betimlenmesi}

Filmin ilk sahnesi Kazım Efendi (Münir Özkul) ve eşi Saadet Hanım’ın (Adile Naşit) işlettiği Asri Cihangir Turşucusu'nun görüntüsüyle açllır. Dükkânın vitrininde özenle yerleştirilmiş envaiçeşit turşu kavanozları vardır. Yaşlı bir adam dükkâna girer. Bu sırada Kazım Efendi camları parlatmakla meşgulken, Saadet Hanım da kasa başındadır. İkisinin de suratı asıktır. Halleri ve birbirlerine tavırlarından tartıştıkları, aralarının hiç iyi olmadığı belli olmaktadır.
Betimleme:
Saadet Hanımla Kazım Bey birbirlerine ters ters bakarlar. Saadet Hanım kasayı açıp, para saymaya başlar.
Nuri Bey:
Kavanozda $1 \mathrm{~kg}$. patlıcan turşusu istiyorum.
Kazım Bey:
Hişştt. Nuri Beye bak.
Saadet Hanım:
Sen bak. Görüyorsun hesap yapıyorum. Dört tane elim yok ya.

Evli orta yaşlı bir çiftin komik atışmalarını anlatan bu sahnede seyircilerin insan ilişkileri ve iletişim hakkındaki mevcut bilgilerine göre varsayımları şunlardır: Bir insan bir işle meşgulse aynı anda başka bir iş yapamaz. Karşısındaki insanın bunu anlamasını bekler. Karşısındaki bir iş yaptığını gördüğü halde hala ondan başka bir iş yapmasını isterse bu durumu iyi karşılamayabilir. Eğer kendisinden iş isteyen kişiyle arası açıksa, diğeri üzerinden atamadı̆̆ı önceki çatışmanın olumsuz tesiriyle ona daha sert tepki gösterebilir. Diyalogu ve olup bitenleri temel alan bağlamsal varsayımlardan ise zaten birbirlerine öfkeli olan çiftin Kazım Bey’in sinirli sinirli hatta nezaketsiz bir üslupla Saadet Hanım'a seslenmesi ve hesap yaptığını gördüğü halde müşteriye bakmasını istediği için onun aynı tonda cevap vermesiyle gerginliğin tırmandığı sonucuna varılabilir. Betimleme metni Saadet Hanım'ın az sonra vereceği cevabı pekiştirir niteliktedir. Saadet Hanım ve Kazım Bey yüzlerinde somurtkan bir ifadeyle birbirlerine ters bakarak, içlerinde duydukları öfke ve düşmanlığı gözlerinde yansitırlar. Aralarında çözemedikleri sorunlar ve anlaşamadıkları konular olduğu için bu şekilde davranırlar. Ters bakışların olduğu bu ortamda gerginlik hâkimdir. Bu gerginlik beden diliyle olduğu kadar sarf edilen sözlerde de kendini hissettirecektir. Karı kocanın birbirlerine nasıl baktıkları betimlemede aktarılmasaydı, görme engelli seyirciler Saadet Hanım'ın kızgınlı̆̆ını sadece o esnada yaşanan durumla ve Kazım Bey’in anlayışsız tutumuyla bağdaştırıp, süregelen bir geçimsizlik olduğunu düşünmeyebilirdi.

Aktörlerin tartışırken kullandıkları jest ve mimikleri, fiziksel özellikleri, ses tonları ve diyalogları bütün olarak ekrana komik kareler olarak yansıyor. Ancak birbirini takip eden diyaloglar arasındaki boşluk süreleri az olduğu için örneğin Adile Naşit’in ufak tefek yapısını, sevimli tombulluğunu veya kaşları

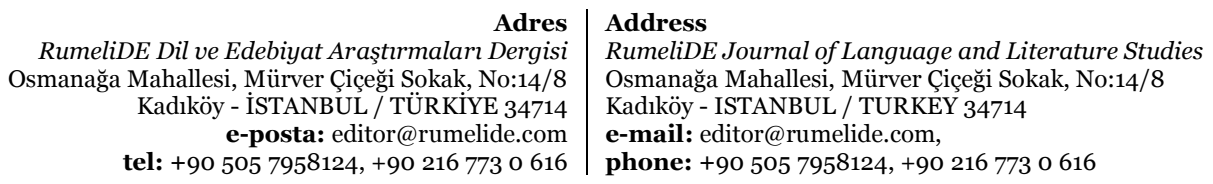


kalkık gözleri yere doğru bakarken bir yandan da kendi kendine şikâyet edercesine başını yana eğip hafifçe salladığını ayrıntılı ifade etmek olanağı bulunmamaktadır. Sesli betimlemede esas olan metin yazarının öznelliğe düşmeden, gördüklerini olduğu gibi hiçbir şey çıkarmadan veya herhangi bir yorum eklemeden anlatması yani görsel öğeleri nesnel bir yaklaşımla ele almasıdır, örneğin yapılan jestleri söylemek yerine tasvir etmek. Bu yaklaşım özünde seyircinin filmle ilgili yorumlarını ve duygularını yönlendirmeden gören seyirciler gibi kendi başına izleme deneyimi yaşamasını sağlamak düşüncesini içerir. Ancak süre yetersizliği, hızlı sahne geçişleri, jest ve mimiklerin çabuk değişmesi, aynı anda farklı karakterlerin yüz ifadelerini anlatma zorunluluğu ve kimi duyguların ancak görüldüğü takdirde anlaşılacak kadar karmaşık olması gibi faktörler çevirmenin öznel ifadeler tercih etmesine neden olabilir (Mazur, 2014: 181-182, 184).

Kazım Bey Saadet Hanım'la boşandıktan sonra onunla kalan üç çocuğuna bakıp hem annelik hem babalık vazifelerini yerine getirmeye çabalar. Seçilen diğer sahnede iki oğlu sofrada kahvaltı ederken Kazım Bey de ütü yapmaktadır. Az önce bahçede kan ter içinde ip atlarken görülen Yaşar'ın sofrada ne var ne yok adeta nefes dahi almadan silip süpürmesi, ortada bir sorun olsa da komik bir görüntü oluşturur. Onun bu halini gören babası kendini tutamaz ve onu uyarma ihtiyacı duyar.

$\begin{array}{ll}\text { Betimleme: } & \begin{array}{l}\text { Yaşar bir yandan yumurtayı bir yandan ekmeği iştahla ağzına tıkıyor. O sırada } \\ \text { ütü yapan babası endişeyle onu izliyor. }\end{array} \\ \text { Kazım Bey: } & \text { Yaşar karışmayım diyorum ama dayanamıorum. } \\ \text { Yaşar: } & \text { Ne oldu baba? } \\ \text { Kazım Bey: } & \text { Daha ne olsun? Az önce 5-10 gram verdin, şimdi } 10 \text { kilo alıyorsun. }\end{array}$

Seyirciler yemek yeme alışkanlıkları ve kilo verme hakkında daha önce edinmiş oldukları bilgilerden hareketle aşırı miktarda yiyecek tüketmenin kilo almaya sebep olduğu ve egzersizin ancak doğru beslenmeyle faydalı olabileceği varsayımlarında bulunabilir. Seyirci bağlamı ele aldığında ise Yaşar'ın yerken kontrolünü kaybettiği için yaptığı egzersizlerin boşa gittiğini hatta kilo vermek şöyle dursun daha çok kilo almasına bile yol açtığını çıkarsayabilir. Baba olarak Kazım Bey’in onun frenleyemediği iştahı karşısında ne hissettiğini yani evladının sağlığını düşünerek kilolu olmasını önemsediğini anlayabilir. Betimleme metninde Yaşar'ın yeme şekli, uzun süre aç kalmış gibi birbiri ardına büyük lokmalar halinde yiyecekleri yiyip yutmaya çalışması ve babasının kaygı dolu bakışlarına değinilmiştir. $\mathrm{Bu}$ bilgiler daha sonra baba oğul arasında geçen diyalogdan yapılan varsayımları güçlendirir ve Yaşar'ın karakteri nedeniyle yeme sorununu çözmenin güç olduğunu seyirciye tekrar bildirirken bir yandan da onu güldürür.

Filmin en komik karelerinden biri Saadet Hanım ve çocukları akşam evde oturmuş, birlikte 1970'li yılların popüler dizisi Küçük Ev’i izlerken yaşanır. Dizide küçük bir çocuğun babası için ağladığı sahneyi izleyen çocuklar hüzünlenir, anneleri ise çok duygulanarak gözyaşlarını tutamaz. Bu sırada Kazım Bey'in evde istemediği kardeşi Ziya (Şener Şen) onları ziyarete gelir, neşesi gayet yerinde hepsine sarılır, kucaklaşırlar. Ziya yengesinin diziyi izleyip durmadan ağlamasına epey şaşırır. Bu durum ona tuhaf geldiği halde tek damla gözyaşı akıtmadan sanki kendisi de çok etkilenmiş gibi davranır. Aslında amacı yengesine sempatik görünüp, ondan yapacağı iş için maddi destek almaktır.

Saadet Hanım:

Ziya:

Betimleme:

Betimleme:
Çok acıklı Küçük Ev bu gece. Bitsin sonra konuşuruz. Otur.

Allah Allah. Ne var Küçük Ev'de ya?

Saadet Hanım içini çeke çeke ağlamaktan kendini alamıyor.

Yengesinin bu halini gören Ziya da ağlar gibi yapıyor.

\footnotetext{
RumeliDE Dil ve Edebiyat Araşttrmalar Dergisi Osmanağa Mahallesi, Mürver Ciçeği Sokak, No:14/8 Kadıköy - İSTANBUL / TÜRKIYE 34714 e-posta: editor@rumelide.com tel: +90 505 7958124, +90 2167730616

Address

RumeliDE Journal of Language and Literature Studies Osmanağa Mahallesi, Mürver Çiçeği Sokak, No:14/8

Kadıköy - ISTANBUL / TURKEY 34714

e-mail: editor@rumelide.com,

phone: +90 505 7958124, +90 2167730616
} 
Saadet Hanım:

Ziya:
Sana da mı dokundu?

Haklısın yenge çok acıklı.

Seyirciler bireylerin hayatın akışı içinde karşılaştığı olaylar ve durumlara verdiği duygusal tepkilerle ilgili geçmiş tecrübelerinden edindiği bilgilere dayanarak ağlamanın üzüntü, acı ve neşe kaynaklı bir dışavurum olabileceği, kadınların erkeklere kıyasla daha duygusal düşündükleri ve hissettiklerini daha rahat yansıttıkları şeklinde varsayımlarda bulunabilir. Sahne bağlamında ise Saadet Hanım ve Ziya açısından şu çıkarımlar yapılabilir: Saadet Hanım şefkatli bir annedir. Dizideki küçük çocuğun acısını anlar ve hayli etkilenir. Özellikle kendi çocuklarını babasız büyüten bir anne olarak empati kurabilir. Aslında dizide ne olduğu Ziya'nın ilgisini çekmez ve etkilenmez. Fakat yengesinin ağlamaya devam ettiğini görünce o da yengesine diziden onun kadar etkilendiğini göstermek için numaradan ağlar görünür. Çabası sonuç verir, yengesi gerçekten üzüldüğüne inanır. Doğal olarak ağlama seslerini seyirci duyar ancak Saadet Hanım'ın kendini dizideki duygu seline ne kadar kaptırdığını pekiştirmek için nasıl ağladığına betimlemede değinilmiştir. Ziya’nın ağlama sesi görüntüyü izlemeden sadece dinleyince kulağa gerçekmiş gibi geldiği için görme engelli seyircinin onun numara yaptığını ayırt etmesini sağlayacak şekilde betimlenmiştir. Ayrıca Ziya bir ara sözde ağlamayı kesip normal haline döner. Ama yengesinin hala ağladığını görünce yüz ifadesini gözünden yaş dahi akmadan birden yine ağlamaklıya çevirir. Aktörün bu jest ve mimikleri sahnedeki komikliğin zirvesidir. Boşluk süresi az olduğu için betimlemede bu görsel unsurlar özetle yer almış ve seyirciye en bağıntılı gelebilecek ifade kullanılarak gülme etkisi kısmen korunmuştur.

Çocuklarının ısrarı üzerine Kazım Bey ve Saadet Hanım'ın onları kıramayıp parkta ilk kez görüştükleri sahnede ikisinin de gerginliğinden oraya gönülsüz geldiği anlaşılır. Karşılıklı ayakta dururken selamlaşmamak için sağa sola havaya bakıp, gözlerini kaçırırlar. Çocuklar onları baş başa bırakıp, yakınlarındaki banklara oturduktan sonra bu huzursuz ama bir o kadar da komik halleri bir süre devam eder. Nihayetinde yüzlerinden düşen bin parça birbirlerinden mümkün olduğu kadar uzak durarak otururlar. Geçen zaman yaşadıklarının üstünü örtemediği gibi duydukları öfke hala o günlerdeki kadar tazedir.
Betimleme:
Aralarında mesafe bırakarak bir banka otururlar. Çocuklar buna sevinerek birbirlerine el sallar. Önce birbirlerine bakmazlar. Sonra Kazım Bey göz ucuyla Saadet Hanımı şöyle bir süzer. Bunu fark eden Saadet Hanım da ona şöyle bir bakar. Bakışları karşılaşınca ikisi de bir hışım başlarını hemen başka yöne çevirirler.
Kazım Bey: $\quad$ Maşaallah iyi gördüm sizi.
Saadet Hanım: Maşaallah siz de iyisiniz.
Kazım Bey: Bakıyorum iyice göbeklenmişsin Saadet Hanım.
Saadet Hanım: $\quad$ Senin de saçların bembeyaz olmuş iyice akbabaya dönmüşsün Kazım Efendi.

Seyirciler aile kavramıla ilgili önbilgilerini temel alarak bireylerin yaşantısında doğup büyüdüğü çekirdek aile ortamı ve aile içi ilişkilerin önemli yer tuttuğu varsayımlarında bulunabilir. Bu sahne için bağlamsal varsayımlar ise Kazım Bey ve Saadet Hanım'ın boşanmış bir çift olarak birbirleriyle kurdukları iletişimin etrafında şekillenir. Çocukları istemeseydi bir araya gelmeyeceklerdi, dolayısıyla iletişimin başlangıcında sorun olduğu için aslında çocukların devamında hemen olumlu bir gelişme beklentisi içinde olmaları gerçekçi bir çıkarım değildir. Çocukların erken sevinmesi bu sahnedeki durumsal gerçekliğe tezat olduğu için betimlemede özellikle belirtilmiştir. İlk anda birbirlerini görmezlikten gelip selam vermeyen Kazım Bey ve Saadet Hanım en sonunda banka oturduklarında bile sanki iki yabancı gibi kişisel mesafe sınırlarını bilinçli olarak geniş tutarlar. Aralarındaki sorunları çözmedikleri için yıllar geçse de bu sorunlar onları rahatsız etmeye devam etmiştir. Bu nedenle 
birbirlerine karşı tutum ve yaklaşımları yapıcı olmaktan uzaktır, hatta fiziksel özellikleriyle ilgili iğneli konuşmaktan bile çekinmezler. İletişimsizlik diyaloglara sözler ve ses tonuyla yansıdığı kadar sözel olmayan unsurlarla yani beden diliyle de kendini açıkça belli eder. Jestler ve mimikler betimlemede görme engellilerin diyaloglardan çıkarsadığı varsayımları güçlendirecek şekilde ayrıntılı olarak anlatılmıştır.

Bu sahneye benzer aynı ölçüde komik bir sahne de Kazım Bey ve Saadet Hanım’ın ikinci kez karşılaşmalarında kızları Zeynep’i (Oya Aydoğan) Uğur (Ahmet Sezerel) ve ailesi istemeye geldiklerinde yaşanır. Kazım Bey ve çocuklar Saadet Hanım’ın evine giderler. Henüz konuklar gelmemiştir. Saadet Hanım çocuklarını çok sıcak karşılar. Ama Kazım Bey’i görünce yüz ifadesi aniden değişir, gülümsemesi kayboluverir. Birbirlerine yakın oturmaktan kaçınan Kazım Bey ve Saadet Hanım göz teması kurmadan soğuk bir selamlaşmada kalırlar.

Zeynep: $\quad$ Gel baba. Şöyle yan yana oturun.

Betimleme: $\quad$ Kazım Bey oturur oturmaz Saadet Hanım'dan uzaklaşır. Koltuğun ucuna ilişir. İkisi de kaşlarını kaldırmış, sağa sola bakarlar. Çocuklar gülerek onların bu hallerini seyreder.

Seyirciler bir kavram olarak ailenin temel özellikleri ve işlevlerine ilişkin önbilgilerine göre bireyin aile içindeki rolü gereği sorumluluk aldığı ve ailede sözlü veya sözsüz etkili iletişimin düzeni sağlamak için önemli olduğu varsayımlarında bulunabilir. Sahne bağlamında ise ebeveynler arasındaki uyumsuzluğun duygusal bağları zedelediği, birbirleriyle kurdukları ilişkinin çocukları etkilediği ve çocukları için mutluluğun onları aynı evde beraber görmek olduğu varsayımları yapılabilir. Betimlemede çiftin evde otururken park sahnesindeki iletişimsizliklerini bir adım daha ileriye taşıdıkları, diyaloga girmeden öfke hissini yüz mimikleriyle açıça ifade ederek hem fiziksel hem de iletişimsel boyutta mesafeyi iyice açtıkları vurgulanmıştır. Ayrıca Zeynep’in hem sözleri hem de davranışlarına yansıyan anne ve babasını bir araya getirme çabası betimlemede diğer çocukların da bunu istediklerini gösteren olumlu tepkileri paylaşılarak pekiştirilir.

\section{Sonuç}

Sesli betimleme görme engellilerin görsel-işitsel ürünlere erişimini sağlayan bir çeviri türüdür. Yerli filmler sesli betimlemenin sıklıkla yararlanıldığı ortamlar arasında yer alır. Sesli betimleme süreci filmde diyaloglar arasındaki boşluklara uygun senaryolaştırılan ek anlatının seslendirilmesini içerir. Boşluk süreleri kısıtlıdır ve arka plan sesleri ile müziğin olabildiğince kesintiye uğramaması gereklidir. Genel itibariyle bu koşulları göz önünde bulundurmak suretiyle görme engellilerin filmi anlayabilmesi için sahnedeki hangi görsel unsurlara betimleme metninde yer verileceğine karar vermek ve bu unsurların dilsel göstergelerle nasıl aktarılacağı önem taşımaktadır. Sesli betimleme farklı yönleriyle ele alınarak çok sayıda araştırmaya konu olabilecek zenginlikte bir alandır. Film türü perspektifinden özellikle geniş çapta seyirci kitlesine hitap eden komedi filmlerinin sesli betimleme süreci ayrıntılı bir biçimde çalışmaya gereksinim duyulan önemli başlıklardan biridir. Bu bakımdan bu makalede Dokuz Eylül Üniversitesi Sesli Betimleme Destek Projesi çıtılarından biri olan Neşeli Günler (1978) adlı Türk aile komedisi ve betimlemeli versiyonu incelenmiştir. Sesli betimleme sürecinde metin yazarlığı yapan çevirmenin isabetli kararlar verebilmesi için görme engelli seyircilerin filmdeki sahneleri nasıl algılayıp, yorumladıklarının yani filmi izlerken zihinde ne tür bilişsel işlemlerin gerçekleştiğinin farkında olması gereklidir. Bu görüşten hareketle bahsedilen komedi filminin sesli betimleme metni Grice'ın çıkarımsal bildirişim modeline dayanan Deidre ve Wilson'un geliştirdiği bağıntı kuramı çerçevesinde bilişsel edimbilimsel bir yaklaşımla irdelenmiştir. Bağıntı kurabileceği uyaranlar insanın ilgisini çeker. Birey herhangi görsel ve işitsel girdiyi artalan bilgisiyle ilişkilendirip, anlamlı sonuçlar

\section{Adres $\mid$ Address}

RumeliDE Dil ve Edebiyat Araşttrmaları Dergisi $\quad$ RumeliDE Journal of Language and Literature Studies Osmanağa Mahallesi, Mürver Çiçeği Sokak, No:14/8 Osmanağa Mahallesi, Mürver Çiçeği Sokak, No:14/8

Kadıköy - İSTANBUL / TÜRKIYE 34714 Kadıköy - ISTANBUL / TURKEY 34714 e-posta: editor@rumelide.com

tel: +90 505 7958124, +90 2167730616 phone: +90 505 7958124, +90 2167730616 
çlkarabilirse o girdi birey için bağıntılıdır. Girdi eski bilgi (mevcut varsayımlar) ve yeni bilgiyle (bağlamsal varsayımlar) ne kadar az zihinsel çaba harcanarak işleme koyulursa ve bu işlemin sonunda ortaya çıkan olumlu bilişsel etki ne kadar fazlaysa o girdi o denli bağıntılı sayılabilir. Komedi filminde gereken bağıntı kurulduğunda ödül olarak seyirciye komik gelen, onun eğlenmesini ve gülmesini tetikleyecek bir durum ortaya çıkar. Sesli betimleme sürecinde çevirmen görme engelli seyircilerde bu eşdeğer etkiyi uyandırmak için izledikleri sahneyle ilgili uygun çıkarımlarda bulunmalarını sağlayan, bağlamda iletilen fakat onların erişemediği görsel bilgiler arasından öncelikli olanları seçip boşluk sürelerine göre filmin anlatısına ekler. Seçilen sahnelerde betimleme metni ve diyaloglar seyircilerin önbilgileri ve sahnede bağlamla gelen yeni bilgilerden en az bilişsel çabayla çıkarsayabilecekleri varsayımlar çerçevesinde irdelenmiş ve sahnedeki komik etkinin hangi görsel unsurların eklenmesiyle seyirciye geçeceği tartışılmıştır. İnsanları güldüren unsurlar kültüre özgü olduğu için çevirmen kültürünü tanımalı ve Türk insanının neleri komik bulduğunu iyi bilmelidir. Neşeli Günler 1970’li yılların toplumunu ve ailesini anlatan bir dönemin komedi filmidir. Bu sebeple çevirmen o dönemde yaşayan insanların komedi anlayışından hareketle betimleme metninin içeriğini oluşturmuştur. Seçilen her sahne filmin akışı içinde kendi koşullarına göre özgün bir çeviri durumu olarak çözümlenmiştir. Beden dili, jest ve mimiklere yansıyan boşanan bir çiftin iletişim kopukluğunun güldürü odağı olduğu filmde boşluk süreleri yeterliyse nesnel bir yaklaşımla hareketler anlatılmış, neye işaret ettikleri söylenmemiştir. Sürenin kısıtlı olduğu yerlerde ise öznel olarak çevirmenin kendi özet yorumu eklenmek suretiyle hareketin anlamına değinilmiştir. Bu çalışmada bağıntı kuramı komedi filminin sesli betimlenmesi bağlamında tartışılsa da diğer film türlerine de benzer şekilde uygulanabilir. Süreçte film türünün özellikleri ve seyirci kitlesi üzerinde uyandırmak istediği etkiler göz önüne alınarak, en az çabayla bu etkilere yönelik işlemlemenin gerçekleşmesini sağlayacak uygun görsel bilgiler ve dilsel yapıların seçilmesi önem taşır. Özünde tüm sesli betimleme uygulamaları erişim kolaylığını hedefler. Görme engelli birey bilgiye ne kadar kolay erişirse, ne kadar hızlı duyduklarını anlayabilirse sesli betimleme de o kadar başarılıdır. Bağıntı kuramı da temelinde etkili iletişim ilkesine dayandığından sesli betimlemeyle ortak paydada buluşması kaçınılmazdır.

\section{Kaynakça}

Doğan, G. (1990). Bir Edimbilim Kuramı Olarak Bağıntı. Dilbilim Araştırmaları,63-72.

Doğan, G. \&Yavuz, H. (2013). Şiir Dili, Bağıntı ve Zayıf Sezdirimler. Bilig 64, 123-150. http://dergipark.org.tr/tr/pub/bilig/issue/25367/267746

Gallai, F. (2019). Cognitive Pragmatics and Translation Studies. Rebecca Tipton, Louise Desilla (Ed.). The Routledge Handbook of Translation and Pragmatics. New York \& Londra: Routledge. https://www.routledgehandbooks.com/doi/10.4324/9781315205564-4. Erişim tarihi 9 Ocak 2020.

Grice, H. P. (1975). Logic and Conversation. Syntax and semantics 3: Speech acts. Peter Cole, Jerry L. Morgan (Ed.). New York: Academic Press. 41-58.

Jakobson, R. (1959). On Linguistic Aspects of Translation. Reuben Arthur Brower (Ed.). On Translation. Cambridge, Massachusetts: Harvard University Press. 232-239. http://web.stanford.edu/eckert/PDF/jakobson.pdf

Kansu-Yetkiner, N. (2009). Çeviribilim Edimbilim İlişkisi Üzerine. İzmir: İzmir Ekonomi Üniversitesi.

Martinez-Sierra, J. J. (2009). The Relevance of Humour in Audio Description. inTRAlinea 11. http://www.intralinea.org/archive/article/1653

Maszerowska, A. (2015). Genre. Aline Remael, Nina Reviers, Gert Vercauteren. (Ed.). Pictures Painted in Words: ADLAB Audio Description Guidelines. AB Yaşam Boyu Öğrenme Programı ADLAB Projesi, Avrupa

Komisyonu. http://www.adlabproject.eu/Docs/adlab\%2obook/index.html\#genre

RumeliDE Dil ve Edebiyat Araștırmaları Dergisi Osmanağa Mahallesi, Mürver Ciçeği Sokak, No:14/8 Kadıköy - ISTANBUL / TÜRKIYE 34714 e-posta: editor@rumelide.com tel: +90 $5057958124,+902167730616$
Address

RumeliDE Journal of Language and Literature Studies

Osmanağa Mahallesi, Mürver Çiçeği Sokak, No:14/8

Kadıköy - ISTANBUL / TURKEY 34714

e-mail: editor@rumelide.com,

phone: +90 505 7958124, +90 2167730616 
Mazur, I. (2014). Gestures and facial expressions in audio description. Anna Maszerowska, Anna Matamala, Pilar Orero. (Ed.). Audio Description: New perspectives illustrated. Amsterdam/Philadelphia: John Benjamins. 179-197.

Neşeli Günler (1978). Yönetmen: Orhan Aksoy. Yapım Şirketi: Arzu Film. https://www.youtube.com/watch?v=FQ_7cabWOvo

Önk, Ü.Y. (2011). Türk Sineması'nda Türler Üzerine Bir İnceleme (1970-1980). Journal of Yaşar University 23(6), 3866-3877.

Remael, A. \& Reviers, N. \& Vercauteren, G. (Ed.). (2015). Preface. Pictures Painted in Words: ADLAB Audio Description Guidelines. AB Yaşam Boyu Öğrenme Programı ADLAB Projesi, Avrupa Komisyonu. http://www.adlabproject.eu/Docs/adlab\%2obook/index.html

Snyder, J. (2008). Audio Description: The Visual Made Verbal. Jorge Diaz Cintas (Ed.). The Didactics of Audiovisual Translation. Amsterdam/Philadelphia: John Benjamins. 191-198.

Şulha, P. (2019). Görsel-İşitsel Çeviri: Görme Engelliler İçin Sesli Betimleme. İstanbul: Çeviribilim Yayınları.

Şulha, P. \& Dalaslan, D. \& Beyaz E. (2019). Sesli Betimleme Destek Projesi. (Yayınlanmamış Proje). Dokuz Eylül Üniversitesi Bilimsel Araştırma Projesi, İzmir.

Wilson, D. \& Sperber, D. (2004). Relevance Theory. Laurence R. Horn, Gregory Ward (Ed.) The Handbook of Pragmatics. Oxford: Blackwell Publishing. 607-632.

Yağbasan, M. \& Ateş, U. (2018). 1980 Öncesi ve 2000 Sonrası Türk Sinemasında Ailenin Temsili. Akademik Bakış Uluslararası Hakemli Sosyal Bilimler Dergisi 67, 26-40. http://dergipark.org.tr/abuhsbd/issue/39323/463437 